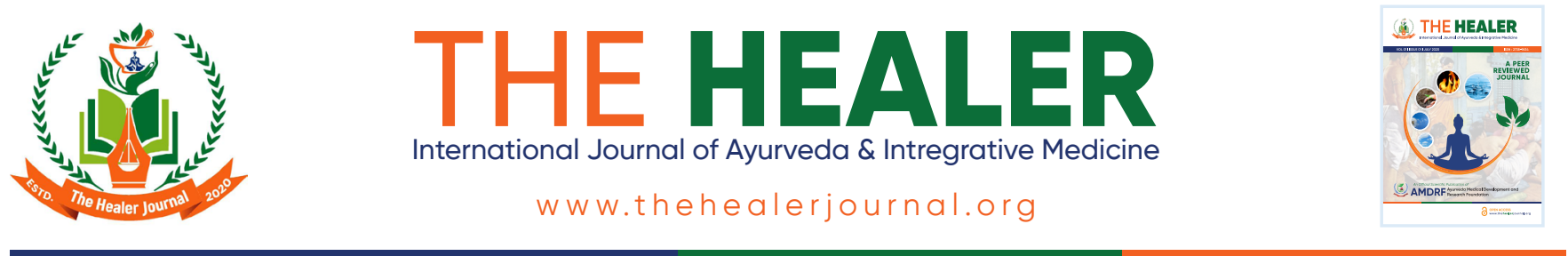

\title{
Editorial
}

\section{Ayurveda and COVID 19 pandemic in Nepal}

\section{BACKGROUND}

World community is facing an unprecedented pandemic of novel corona virus disease (COVID-19) caused by Severe Acute Respiratory Syndrome Corona virus 2 (SARS$\mathrm{CoV}-2)$. The disease has spread globally with the case fatality rate of $3 \%$ showing more than 47.6 million confirmed cases, 3.5 million recovered cases and 1.22 million deaths as of November 5, $2020^{1}$.

Despite being a close neighbor country of China where the outbreak first erupted, and India 185974 confirmed cases, 148408 recovered cases and 1052 deaths have been reported by November 5, 2020 in Nepal where the case fatality rate has been recorded 0.57 percent $^{2}$. Initially, 32 year old student was the first case detected COVID 19 positive on January 25, 2020 who returned from the Wuhan University of Technology, Hubei province, China on January 9, 2020 and he was reported to be recovered ${ }^{3}$. From March 23 to April 2, 2020, five new cases were detected after a two months interval since the first case reported. All these cases were history of foreign travelling. On April 4, 2020, three more new cases we detected including one case of having local transmission of infection. The case of local transmission of COVID 19 was found in Kailali district, a Far western province of Nepal. It was suspected to be transmission of stage II as per the WHO guidelines ${ }^{4-6}$.

Since COVID 19 was reported in January, Government of Nepal announced suspension of visa-on-arrival service for

\begin{tabular}{|c|c|}
\hline \multicolumn{2}{|c|}{ Access the article online } \\
\hline Quick Responde Code \\
\hline \\
\cline { 2 - 2 }
\end{tabular}

nationals of five countries badly affected by COVID-19 such as China, South Korea, Japan, Italy and Iran on March 1, 2020 which was enforced from 7 to 30 March ${ }^{7}$. The government also urged the general public to avoid gatherings including conferences, assemblies and feasts to prevent the outbreak of coronavirus ${ }^{2}$. The Supreme Court issued an interim order to suspend flights to and from countries affected by the disease, in response to public interest litigation. Furthermore, the Government of Nepal expanded the suspension of visa-on-arrival service including three additional countries such as France, Germany and Spain ${ }^{8}$.

Despite worldwide efforts to contain it, the pandemic is continuing to spread for dearth of a clinically proven prophylaxis and therapeutic strategy. The dimensions of pandemic require an urgent harnessing of all knowledge systems available globally. Utilization of Traditional Chinese Medicine in Wuhan to treat COVID-19 cases sets the example demonstrating that traditional medical systems can contribute to treat COVID-19 cases successfully. it is estimated that once all active cases are closed in China, there might expect the case fatality rate (CFR) to be around $3.85 \%$. In November 5, 2020, the global confirmed case fatality rate (CFR) is $3 \%$ in average. Moreover CFR of COVID 19 in Italy, America, Brazil, India and Nepal are $12.08 \%, 3.02 \%, 3.06 \%, 1.5 \%$ and $0.57 \%$ respectively ${ }^{10}$. This pattern of fluctuating CFRs is not surprising during this phase of an outbreak. CFR is a hard outcome and has crucial

\section{*Corresponding Author:}

\section{Dr. Bijendra Shah}

Teaching Assistant, Department of Shalya Tantra, Ayurveda Campus, Institute of Medicine, T.U., Kirtipur, Kathmandu, Nepal

E-mail: bijendrashah17@gmail.com

Submitted: 27.04 .2020

Received: 29.04 .2020

Revised: 12.06 .2020 
part in forming strategies at national and international levels from a public health perspective. It is imperative that health care leaders and policy makers are guided by estimates of mortality and case fatality. However, several factors can restrict obtaining an accurate estimate of the CFR. The virus and its clinical course are new, and we still have little information regarding it. Health care capacity and capability factors including the availability of healthcare professionals, resources, medical facilities, and preparedness, also affect outcomes ${ }^{11}$. Developing countries like India and Nepal have less health professionals, resources and medical facilities to mitigate COVID 19 cases, though CFR of these countries are very few as compared to well equipped with highly sophisticated medical facilities in the world. One of the reasons might be awareness of traditional medicine uses, and Yoga and Pranayama practices for anxiety, stress and depression, which help to enhance immunity and protect or minimize spread of the virus at their own level in the communities.

\section{Ayurveda amid COVID 19 Pandemic}

Drawing on the Ayurveda classics, contemporary scientific studies, and experimental knowledge on similar clinical settings, notwithstanding the fact that no system of medicine has any evidence-based treatment for COVID-19 yet ${ }^{12}$. In Nepal, Ministry of Health and Population of Government of Nepal has implemented Ayurveda and Alternative medicines guidelines of preventive measures and management protocol for COVID 19 pandemic that includes pranayama and Yoga for reducing stress and anxiety; immune-promoting Ayurvedic herbs and Ayurvedic polyherbal or herbominerals medicines for symptomatic treatment ${ }^{13}$. Nadi Suddhi, Bhastrika and Kapala-bhati are the most frequently used pranayama; and have frequently been recommended for COVID-19 patients for 30 minutes. It has been shown effective against stress and anxiety ${ }^{14-19}$. Shankarappa, et al. ${ }^{20}$ reported that among 50 adults who underwent Pranayama practice, that there was a statistically significant increase in pulmonary function. Interferon (IFN) Gamma is also secreted from NK cells which help pro-inflammatory function by activating macrophages and endothelial cells. Structured yoga has also shown to decrease IL-6, TNF alpha, and IL-1 beta 3 production and ultimately reduces inflammation $^{17-19}$, an immune enhancing response against COVID-19 inside the body. Furthermore, the guidelines consists of immune-modulating medicinal herbs such as Tinospora cordifolia Linn., Glycyrhiza glabra, Piper longum, Zingiber officinalis, Termenalia chebula, Emblica officinale; Withania somnifera, Cinnamomum zeylanicum as anti-oxidant; Ocimum sanctum, Allium sativum as antiviral agents; and Mentha arvensis, Cinnamomum tamala, Foeniculum vulgare as anti-inflammatory agents. A herbomineral combination of Tinospora cordifolia ${ }^{21}$ (Gauche in sanskrit, Gurjo in Nepali), Trikatu; a mixture of equal proportion of fruits of Piper longum Linn. (Pippali) and Piper nigrum Linn. (Marich), and Zingiber officinale Linn. (Sunthi) rhizomes and an incinerated (Bhasma) mineral has been administrated in asymptomatic patients at a COVID 19 dedicated hospital in Kathmandu valley, and reported that more than fifty percent of real time polymerase chain reaction (RT-PCR) test of the COVID-19 patients was found negative in 7 days and others got negative in 10 to 14 days $^{22}$. It has supported uses of Guduchi, Trikatu and other medicinal herbs and its products listed in Ayurveda and Alternative Medicines guidelines and management protocol for COVID 19 pandemic. Similar guidelines and protocol of AYUSH medicines has been prepared by AYUSH ministry, Government of India, and implemented through using all means of communication and informations ${ }^{23}$.

Nepal Health Research Council has taken ethical approval of open level two arms controlled trial for a polyherbal Ayurvedic formulation containing Yashtimadhu and Trikatu powders, in mild to moderate COVID 19 cases $^{24}$.

A recent study of molecular docking provides scientific basis in terms of binding of active ingredients present in Yashtimadhu with SARS-CoV-2 target proteins. This study reveals that Glycyrhiza glabra (Yashtimadhu) may inhibit the viral severity by interfering with viral entry as well as its multiplication in the infected persons, and thus Yashtimadhu may be helpful in the prevention and management of the COVID-1925. The Institute of Medical Sciences, Banaras Hindu University, India is going to start a study of using Ashwagandha (Withania somnifera Linn.) as a test drug for prophylactic use among frontline health workers and Yashtimadhu for adjuvant therapy with the standard treatment of conventional medicine on Covid-19 patients with mild and moderate symptoms ${ }^{26}$. A pragmatic approach suggested using decoction of a combination of Ayurvedic herbs including T. cordifolia, Z. officinale, $C$. 
longa, Ocimum sanctum, Glycyrrhiza glabra, Adhatoda vasica, Andrographis paniculata, Swertia chirata, Moringa oleifera, Triphala and Trikatu in exposed asymptomatic (quarantined) cases. These herbs are proposed for the reason that these are known to be broad-spectrum antivirals and protease inhibitors ${ }^{12}$.

\section{Way forward}

Many medicinal herbs having properties of immunity enhancing and antiviral activities are exhibited promising results among the COVID 19 cases at the preliminary evaluation. Therefore, the well known medicinal herbs for COVID-19 should be tested through designing clinical interventions which are today need to mitigate COVID 19 through Ayurveda. The preliminary evidences exhibited for Ayurveda system of medicine requires immediate implementation. It will facilitate learning, generate evidence and shall be a way forward.

\section{N. N.Tiwari, TS Dudhamal, Shiv Mangal Prasad, Raj Kishor Shah, Bishun D. Patel, Bijendra Shah \\ REFERENCES}

1. WHO. https://covid19.who.int/WHO Coronavirus Disease (COVID-19) Dashboard.accessed date 2020/11/5, 10:36am CET. 2020.

2. MOHP. Government of Nepal. Ministry of Health and Population. https://covid19.mohp.gov.np/Nepal's latest Update on COVID-19 2020. accessed on November 5, 2020. 2020.

3. Bastola A, Sah R, Rodriguez-Morales AJ, et al. The first 2019 novel coronavirus case in Nepal. The Lancet Infectious Diseases. 2020;20(3):279-280.

4. Joshi J, Mishra P, Kamar SB, et al. Clinical Profile of Cases of COVID-19 in Far Western Province of Nepal. Journal of Nepal Health Research Council. 2020;18(1):135-137.

5. Gao J, Zheng P, Jia Y, et al. Mental health problems and social media exposure during COVID-19 outbreak. Plos one. 2020;15(4): 0231924.

6. Anonymous. Covid-19: First locally transmitted case confirmed in Nepal. The Himalayan Times. Assessed on 3 April 2020. https://thehimalayantimes.com/nepal/ covid-19-firstlocally-transmitted-case-confirmed-innepal/. 2020.

7. CAA. COVID 19. Government of Nepal. Ministry of Culture, Tourism and Civil Aviation. . 2020.

8. MOFA. Government of Nepal, Ministry of Foreign Affaires. Department of Immigration. In response of

\section{COVID 192020.}

9. Spychalski P, Błażyńska-Spychalska A, Kobiela J. Estimating case fatality rates of COVID-19. The Lancet. Infectious Diseases. 2020.

10. WHO. https://covid19.who.int/.WHO Coronavirus Disease (COVID-19) Dashboard. Accessed on 5 September, 2020. 2020.

11. Rajgor DD, Lee MH, Archuleta S, Bagdasarian N, Quek SC. The many estimates of the COVID-19 case fatality rate. The Lancet Infectious Diseases. 2020;20(7):776777.

12. Rastogi S, Pandey DN, Singh RH. COVID-19 Pandemic: A pragmatic plan for Ayurveda Intervention. Journal of Ayurveda and Integrative medicine. 2020.

13. Prasad S, Patel, BD. Ayurveda Guidelines of Preventive Measures and Curative Management Protocol for COVID 19 in Nepal. 2020.

14. Brown RP, Gerbarg PL. Sudarshan Kriya yogic breathing in the treatment of stress, anxiety, and depression: part I-neurophysiologic model. Journal of Alternative \& Complementary Medicine. 2005;11(1):189-201.

15. Brown RP, Gerbarg PL. Yoga breathing, meditation, and longevity. Annals of the New York Academy of Sciences. 2009;1172(1):54.

16. Kaley-Isley LC, Peterson J, Fischer C, Peterson E. Yoga as a complementary therapy for children and adolescents: a guide for clinicians. Psychiatry (Edgmont). 2010;7(8):20.

17. Rathore M, Abraham J. Implication of asana, pranayama and meditation on telomere stability. International journal of yoga. 2018;11(3):186.

18. Kochupillai V, Kumar P, Singh D, et al. Effect of rhythmic breathing (Sudarshan Kriya and Pranayam) on immune functions and tobacco addiction. Annals of the New York Academy of Sciences. 2005;1056(1):242252.

19. Mahendra J, Mahendra L, Ananthalakshmi R, Parthiban PS, Cherukuri S, Junaid M. Effect of Pranayama on Ppar- $\gamma$, Nf- $\kappa$ B Expressions and Red Complex Microorganisms in Patients with Chronic Periodontitis-A Clinical Trial. Journal of Clinical and Diagnostic Research: JCDR. 2017;11(6):ZC82.

20. Shankarappa V, Prashanth $P$, Annamalai N, Varunmalhotra. The short term effect of pranayama on the lung parameters. Journal of clinical and Diagnostic Research. 2012;6(1):27-30.

21. Risingnepaldaily. https://risingnepaldaily.com/ miscellany/ayurvedic-medicines-rendered-to-covid-19patients-in-syangja. 2020.

22. Annapurnapost. Kitchen herbs for fight of CORONA 
Virus. Assessed on 26 August 2020. http:// annapurnapost.com/news/164561. 2020.

23. Tillu G, Salvi S, Patwardhan B. AYUSH for COVID-19 management. Journal of Ayurveda and Integrative Medicine. 2020;11(2):95.

24. Kantipurdailynews. https://ekantipur.com/news/2020/0 9/13/159995720958368631.html?fbclid=IwAR10cAht tB94BF7D372-s32pg4ZeE6KcE7gGnvbVyboEELUms WDfmg_en40. accessed on 5 November, 2020. 2020.

25. Maurya DK. Evaluation of Yashtimadhu (Glycyrrhiza glabra) active Phytochemicals Against Novel Coronavirus (SARS-CoV-2). 2020.

26. TimesofIndia. Varanasi: IMS BHU to test Ashwagandha, Yashtimadhu use in COVID therapy. Accessed on 4 September, 2020. http:// timesofindia.indiatimes.com/articleshow/76928535. cms?utm source=contentofinterest\&utm medium=text\&utm_campaign=cppsthttps:// timesofindia.indiatimes.com/city/varanasi/ims-bhu-totest-ashwagandha-yashtimadhu-use-in-covid-therapy/ articleshow/76928535.cms. 2020.

How to cite this article:

Tiwari NN, Dudhamal TS, Prasad SM, Shah RK, Patel BD, Shah B, Ayurveda and COVID 19 pandemic in Nepal, The Healer Journal, 2020;1(1):I-IV. 